\title{
How to handle state-owned enterprises in EU-China investment talks
}

\author{
Alicia García-Herrero and Jianwei Xu
}

ALICIA GARCÍA-HERRERO

(alicia.garcia-herrero@ bruegel.org) is a Senior Fellow at Bruegel.

JIANWEI XU (jianwei.xu@ bruegel.org) is a visiting scholar at Bruegel.

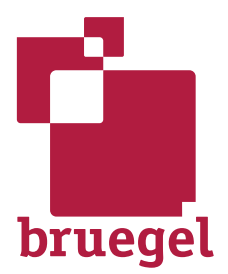

\section{Executive summary}

CHINESE STATE-OWNED ENTERPRISES (SOES) are one of the main obstacles preventing China and the European Union from agreeing a bilateral investment agreement (BIT). Given the benefits that both China and EU could obtain from a BIT, the question of SOEs should be addressed in the most effective way.

WE EXAMINE THE main differences between Chinese and European SOEs, in terms of their sectoral coverage and, most importantly, their corporate governance. We argue that preferential market access for Chinese SOEs in China is the key to their undue competitive advantage globally, and is also the reason why global consumers might not necessarily benefit from Chinese SOEs in terms of welfare gain.

PREFERENTIAL MARKET ACCESS IN CHINA, rather than ownership of SOEs, should be the key factor when evaluating the undue advantage enjoyed by Chinese corporates because private companies with ties to the Chinese government might also benefit from preferential market access.

WE ALSO OFFER a checklist of issues for EU-China investment talks in relation to Chinese SOEs. First, creating barriers to prevent Chinese companies acquiring European assets will not solve the problem. Instead, equal market access in China is a much better goal to pursue in order to reduce the seemingly unlimited resources that Chinese SOEs seem to have to compete overseas. Second, bringing Chinese corporate governance closer to global market principles is also essential to ensure European and Chinese corporates operate on an equal footing in their cross-border investment decisions. 


\section{Introduction}

Although trade between the European Union and China has been soaring, bilateral investment has remained moderate. Only quite recently has Chinese outward foreign direct investment (FDI) in the EU started to rise substantially, but there is increasing uncertainty about whether this can continue. At the same time, European FDI in China has remained stagnant as European companies increasingly struggle on the Chinese market.

Aware of the potential benefits of FDI, the EU and China have been negotiating a bilateral investment treaty (BIT) for more than three years, with the objectives of unifying and further relaxing restrictions on FDI, and of putting on an equal footing Chinese and EU investors and EU member states, most of which already have BITs with China. In the same vein, the United States has also been negotiating a BIT with China.

While the content of the negotiations is not fully disclosed, either for the US or the EU BIT with China, there are enough official statements and even official updates on the negotiations from European Commission to argue that the dominance of state-owned enterprises (SOEs) in China is clearly a difficult issue. More specifically, the EU argues that SOEs do not follow market principles fully, partly because of the explicit or implicit government support they receive, and this undermines market efficiency. In addition, there is also a disagreement over how to settle disputes between investors, in particular those that involve SOEs. The treatment of SOEs seems to have become one of the most contentious aspects of the ongoing negotiations on an EU-China BIT.

We suggest ways in which the EU and China can enhance their bilateral investments while protecting their interests and understanding the differences in their economic structures. In other words, China, with an economy that continues to be state-driven to a considerable extent, will need to make changes to allow for equal treatment in market access, while the EU will need to acknowledge the role that SOEs play in China's economic model.

We start with a comparison between the roles played by Chinese SOEs and by their European counterparts, finding striking differences in their sectoral coverage. We then look at two major concerns about Chinese SOEs: preferential treatment by government, and their non-commercial objectives. Though these concerns might be justified, there could be similar concerns about private companies, especially if they are large enough and operate in strategic sectors in which natural security could potentially be at stake. On this basis, we offer guidelines on the treatment of SOEs in a potential EU-China BIT. The key issue is market access in China, to guide Chinese SOE behaviour in Europe and to ensure European companies in China can operate on an equal footing. We argue that focusing on market access - rather than on type of ownership - is more relevant for the EU-China BIT negotiations. Finally, we consider the SOE chapter of the recently concluded EU-Vietnam free trade agreement (FTA) ${ }^{1}$ as a potential benchmark for the ongoing negotiations between China and the EU.

\section{The EU-China investment relationship}

Economic cooperation between China and the EU has increased over the past thirty years to the point where the EU is now China's largest trading partner, and China is the EU's second largest trading partner after the United States. Nevertheless, bilateral FDI has until quite recently remained relatively subdued, especially China's outward FDI. In 2011, China's outward FDI (including that from Hong Kong) accounted for only 1 percent of EU total inward FDI, whereas China took 3.5 percent of the EU's outward FDI. Given the size of the Chinese economy in the world already in 2011, this can be considered relatively modest.

1 At time of writing, the EU-Vietnam free trade agreement had been reached but not implemented. 
More recently, Chinese have entrepreneurs started to head abroad for direct investment and Chinese FDI in the EU has scaled up. The push factor for Chinese investors has been decreasing returns on domestic investment; the pull factor has been more availability of potential investments since the global financial crisis and their relatively lower cost. Against this backdrop, Chinese FDI in the EU soared to about $€ 20$ billion in 2015. The EU has become one of China's key destinations, accounting for 41.9 percent of China's total direct investment in the developed economies . Chinese FDI has also become increasingly relevant for the EU, making up 8 percent of FDI inflows in 2015. Meanwhile, EU investment in China has been quite erratic during the last few years, but did decrease substantially from $€ 20.9$ billion in 2013 to $€ 6.9$ billion in 2015 (Figures 1 and 2). The closer investment relationship between China and the EU is more apparent in their relative shares compared to other partners, with China's share leaping significantly in 2014 (Table 1).

\section{Figure 1: Chinese FDI transactions in the EU [€ millions]}

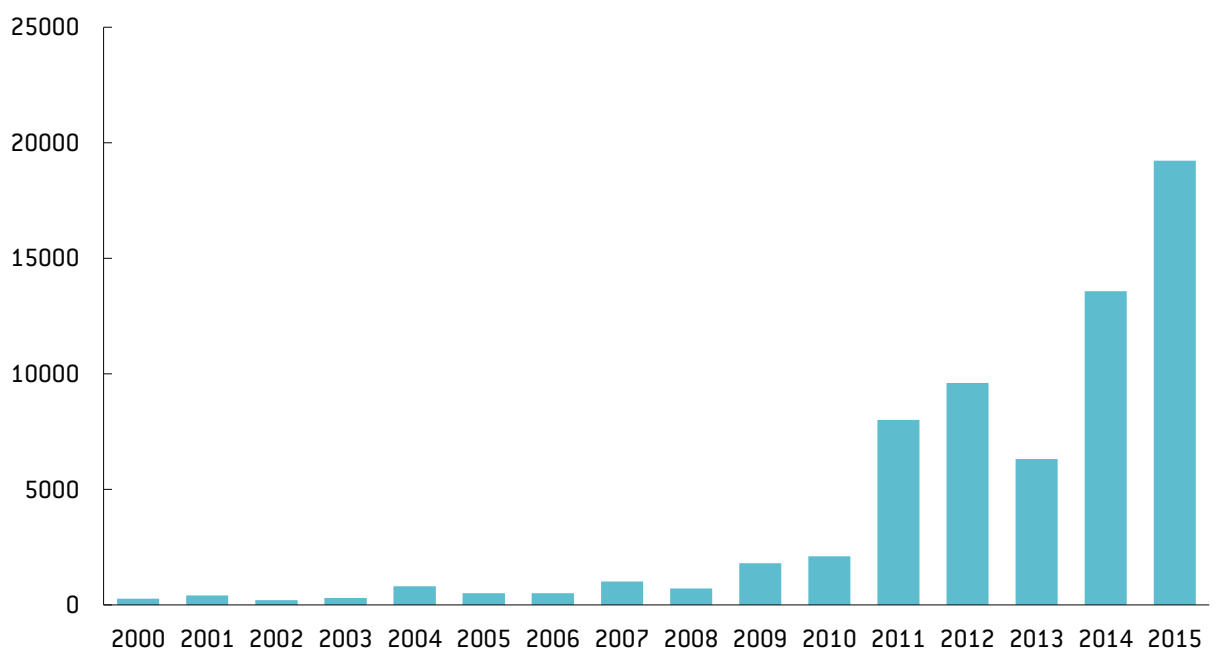

Source: Bruegel based on Hanemann and Huotari (2016).

Figure 2: EU FDI transactions in China [€ millions]

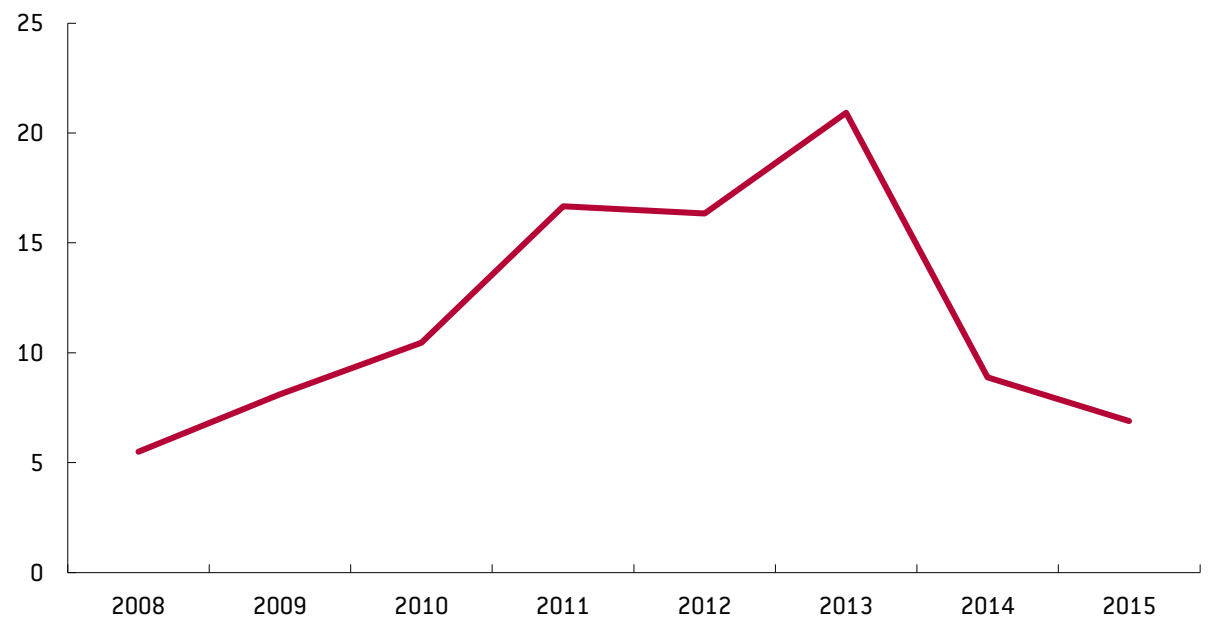

Source: Bruegel based on Eurostat. 
Table 1: Partners' shares of EU outward and inward FDI

\begin{tabular}{lcccccccc}
\hline & \multicolumn{3}{c}{ Outward FDI flows } & \multicolumn{5}{c}{ Inward FDI flows } \\
\hline & 2011 & 2012 & 2013 & 2014 & 2011 & 2012 & 2013 & 2014 \\
\hline $\begin{array}{l}\text { Europe (non- } \\
\text { EU, including } \\
\text { EFTA) }\end{array}$ & $20.92 \%$ & $23.24 \%$ & $10.63 \%$ & $-68.12 \%$ & $13.27 \%$ & $21.75 \%$ & $-0.56 \%$ & $43.27 \%$ \\
\hline United States & $34.26 \%$ & $39.44 \%$ & $50.19 \%$ & $-142.85 \%$ & $60.97 \%$ & $38.62 \%$ & $69.60 \%$ & $-25.10 \%$ \\
\hline Japan & $3.51 \%$ & $5.15 \%$ & $3.83 \%$ & $15.14 \%$ & $1.03 \%$ & $2.73 \%$ & $1.30 \%$ & $7.97 \%$ \\
\hline China & $0.91 \%$ & $0.31 \%$ & $1.50 \%$ & $-0.99 \%$ & $2.43 \%$ & $0.57 \%$ & $1.91 \%$ & $10.70 \%$ \\
\hline
\end{tabular}

Source: Bruegel based on Eurostat.

In terms of Chinese FDI in Europe, there has also been a sea-change in terms of destination. A decade ago, Chinese FDI was concentrated in the European 'big three' economies (Germany, the UK and France). But by 2015, southern European economies accounted for almost half of all Chinese direct investment in the EU.

The rapid increase in FDI has triggered more frequent high-level exchanges between EU countries and China, and has occasionally led also to frictions and disputes. To further eliminate obstacles to bilateral FDI, China and the EU started to negotiate a BIT in November 2013. This has not happened in a vacuum as nearly all EU countries (except Ireland) already have a BIT in place with China; most of these treaties were agreed between the 1980s and early 1990s. The objectives of those treaties, however, were to bring FDI into China while protecting the legitimate operations of foreign businesses. The role of China in the global economy has changed and these old treaties clearly need to be updated. Some EU countries have upgraded their BITs with China (Table 2). The other very relevant reason to revisit the existing treaties between China and EU countries is that the responsibility for agreeing BITs is longer in the hands of member states, since the agreement of the Lisbon Treaty in 2009. Negotiation of BITs is now the responsibility of the European Commission and a new EU-China BIT would cover the whole of the EU.

In the absence of an EU-China BIT, there are wide disparities between the existing BIT treaties between China and EU member countries. In particular, China and central and eastern European countries have established the $16+1^{2}$ initiative to intensify and expand economic cooperation in a wide range of areas, including investment. The initiative seeks to enhance cooperation in three key fields: infrastructure, high technology and green technology. While these policies are generally handled at the level of member states, they are coordinated at European level. In some instances, such as transportation, EU planning financing coordination is involved ${ }^{3}$. The fact that China negotiates bilaterally with these countries potentially complicates that coordination, and also reduces the negotiating power of the EU as a whole. This is why the 16+1 initiative may be thought of as a strategy for China to influence EU policies from within, primarily with the aim of forcing through policies that are favourable to China ${ }^{4}$.

2 The $16+1$ format covers China, 11 EU countries and 5 Balkan countries (Albania, Bosnia and Herzegovina, Bulgaria, Croatia, the Czech Republic, Estonia, Hungary, Latvia, Lithuania, Macedonia, Montenegro, Poland, Romania, Serbia, Slovakia and Slovenia).

3 For example, the EU initiative to foster the Trans-European Transport Network (TEN-T).

4 Dragan Pavlicevic, 'China in Central and Eastern Europe: 4 Myths', The Diplomat, 16 June 2016. 
Table 2: China's existing BITs with EU member states

\begin{tabular}{|c|c|c|c|}
\hline & Signature Date & Valid Date & Remarks \\
\hline \multirow{2}{*}{ Sweden } & 29/03/1982 & 29/03/1982 & \\
\hline & $27 / 09 / 2004$ & $27 / 09 / 2004$ & Valid since signature \\
\hline \multirow{2}{*}{ Germany } & $10 / 07 / 1983$ & 18/03/1985 & \\
\hline & $01 / 12 / 2003$ & $11 / 11 / 2005$ & re-signed \\
\hline \multirow{2}{*}{ France } & $30 / 05 / 1984$ & 19/03/1985 & \\
\hline & $26 / 11 / 2007$ & $20 / 08 / 2010$ & re-signed \\
\hline \multirow{2}{*}{ Belgium and Luxembourg } & 04/06/1984 & 05/10/1986 & \\
\hline & 06/06/2005 & $01 / 12 / 2009$ & re-signed \\
\hline \multirow{2}{*}{ Finland } & 09/04/1984 & $26 / 01 / 1986$ & \\
\hline & $15 / 11 / 2004$ & $15 / 11 / 2006$ & re-signed \\
\hline Norway & $21 / 11 / 1984$ & 10/07/1985 & \\
\hline Italy & 28/01/1985 & $28 / 08 / 1987$ & \\
\hline Denmark & 29/041985 & 29/04/1985 & \\
\hline \multirow{2}{*}{ Netherlands } & $17 / 06 / 1985$ & $01 / 02 / 1987$ & \\
\hline & $26 / 11 / 2001$ & $01 / 08 / 2004$ & re-signed \\
\hline Austria & $12 / 09 / 1985$ & $11 / 10 / 1986$ & \\
\hline UK & $15 / 05 / 1986$ & $15 / 05 / 1986$ & \\
\hline Poland & 07/06/1988 & 08/01/1989 & \\
\hline \multirow{2}{*}{ Bulgaria } & $27 / 06 / 1989$ & $21 / 08 / 1994$ & \\
\hline & $26 / 06 / 2007$ & $10 / 11 / 2007$ & re-signed \\
\hline Hungary & 29/05/1991 & 01/04/1993 & \\
\hline Czech and Slovak & $12 / 04 / 1991$ & $01 / 12 / 1992$ & \\
\hline Slovak & $07 / 12 / 2005$ & $25 / 05 / 2007$ & new revision \\
\hline \multirow{2}{*}{ Portugal } & 03/02/1992 & 01/12/1992 & \\
\hline & 09/12/2005 & $26 / 07 / 2008$ & re-signed \\
\hline \multirow{2}{*}{ Spain } & 06/02/1992 & 01/05/1993 & \\
\hline & $24 / 11 / 2005$ & 01/07/2008 & re-signed \\
\hline Greece & 25/06/1992 & $21 / 12 / 1993$ & \\
\hline Croatia & 07/06/1993 & 01/07/1994 & \\
\hline Estonia & 02/09/1993 & 01/06/1994 & \\
\hline Slovenia & $13 / 09 / 1993$ & 01/01/1995 & \\
\hline Lithuania & 08/11/1993 & 01/06/1994 & \\
\hline \multirow{2}{*}{ Romania } & $12 / 07 / 1994$ & 01/09/1995 & \\
\hline & $16 / 04 / 2007$ & $01 / 09 / 2008$ & revised \\
\hline Malta & $22 / 02 / 2009$ & 01/04/2009 & \\
\hline Cyprus & $17 / 01 / 2001$ & $29 / 04 / 2002$ & \\
\hline
\end{tabular}

Source: Chinese Ministry of Commerce.

At the same time, there are two main reasons for the European Commission to push for a BIT with China. First, since the Lisbon Treaty was signed in 2009, the Commission has had full responsibility for investment issues. Second, the Commission wants to avoid unfair competition between EU countries for Chinese investment. 
In this context, the EU and China have agreed to pursue a deal that would protect investment, increase market access and address key challenges related to the regulatory environment, including those related to transparency, licensing and authorisation ${ }^{5}$. Although most of these issues are covered by existing bilateral agreements, an EU-level BIT with China provides a new opportunity to further reduce barriers to investment and boost bilateral FDI. The BIT also offers great benefits to China, given the rapid increase in Chinese investment in European Union countries in the last few years. Furthermore, a successful EU-China BIT could pave the way to a potential free trade agreement (FTA).

The twelfth round of EU-China BIT negotiations was wrapped up in September 2016 in Brussels. On a number of issues, however, there is no clear convergence between the two negotiating parties. A key point of difference appears to be market access. Market access for EU investors in China is restricted. China is one of the most restrictive countries in terms of market access for foreign investors, according to an index of restrictiveness in market access compiled by the $\mathrm{OECD}^{6}$. Beyond market access, EU authorities are concerned about potential discrimination against EU investors operating in China, including explicit or implicit preferential subsidies for certain enterprises. Such discrimination may also be a factor for Chinese companies operating in Europe. While market access is a more general issue, potential discrimination by means of implicit or explicit subsidies has linkages to the role played by Chinese SOEs. This is not only true for the Chinese economy, but also for Chinese investment in Europe because a good part of it (most of it until very recently) originates from SOEs.

As such, understanding the behaviour of Chinese SOEs, including how they differ from their European counterparts, is crucial for any further negotiations on the EU-China BIT.

\section{What is special about SOEs? A comparison between the EU and China}

Theoretically, the most convincing justification for the existence of SOEs is achieving social objectives and/or correcting market failures. As such, most SOEs do not need to pursue a profit maximisation objective, and are often strictly regulated and assessed by government. In China, SOEs have a much wider scope as they originate from the planned economy era when they dominated all sectors (either SOEs or collectively-owned companies). Most Chinese SOEs, even now, are not established on the basis of correcting market failure, but more to carry out government objectives.

\section{Chinese SOEs: bigger, more pervasive and more dominant than their EU counterparts}

Although China started on its path of market reform and openness in the 1980s, it was only in the 1990s that reform started to have an impact on SOEs - a movement that happened under the slogan 'Grasping the large, letting go of the small'. The aim of that wave of reform was to limit the influence of the government over small-scale SOEs by transforming them into private firms or merging them with large state-owned enterprises. As a result, the number of SOEs declined more rapidly than SOEs' share of employees (Figure 3). In other words, SOEs became larger on average. Another important consequence was that a good part of the private firms existing in China today were SOEs until the late 1990s, meaning their current owners still have connections, directly or indirectly, with the Chinese government.

5 European Commission, DG Trade, 'EU and China agree on scope of the future investment deals', 15 January 2016, available at http://trade.ec.europa.eu/doclib/press/index.cfm?id=1435.

6 OECD Database: FDI regulatory restrictiveness index, updated on 27 March 2017. 
Figure 3: Chinese SOEs, shares of employees and profits

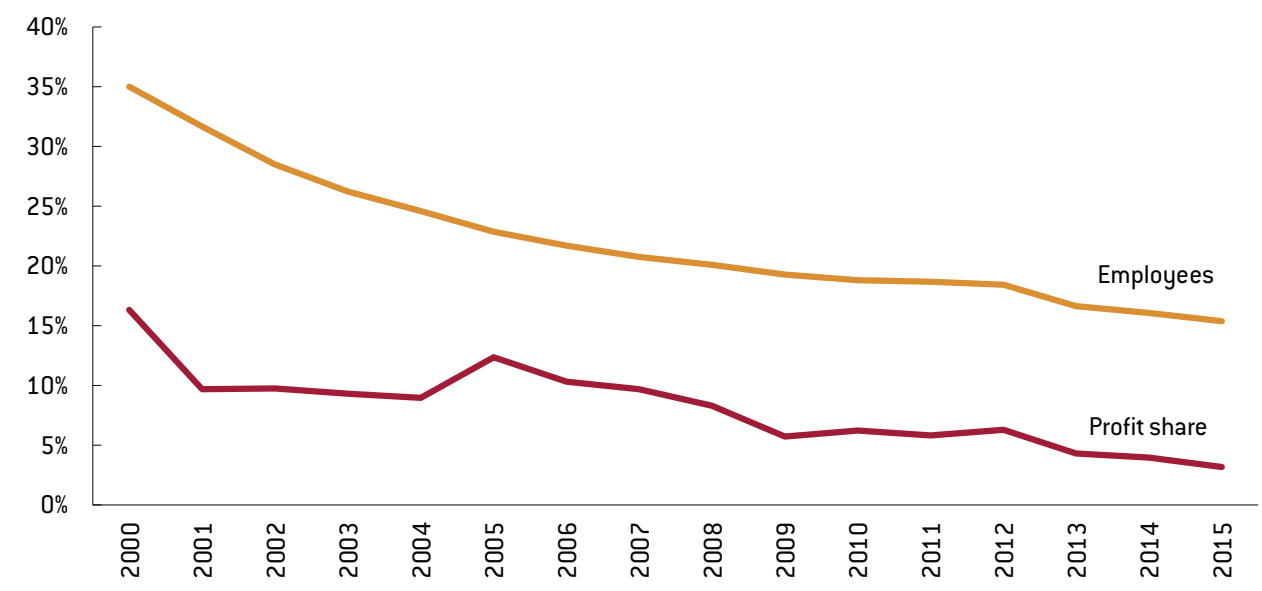

Source: Bruegel based on China Statistics Yearbook. Note: Data for number of SOEs is missing from 2003-05, so the plots are smoothed over the three year period.

Since the late-1990s reforms, the Chinese government has pursued a number of initiatives to reform SOEs, but the logic has switched away from privatisation to improving efficiency while maintaining the role of the state in the production of goods and services. The ultimate objective of the ongoing reform has shifted to creating corporate giants that can compete globally ${ }^{7}$. Those giants remain state-controlled, especially in strategic sectors. Nearly 70 percent of the Chinese firms in the Forbes Global 2000 list of the world's largest public companies are $\mathrm{SOEs}^{8}$. However, in terms of the share of SOEs in the market value of its largest companies, China ranks third globally after Qatar and the United Arab Emirates (OECD, 2016).

State-owned enterprises in the EU are of a very different nature. They are generally smaller than Chinese SOEs. They are typically found in sectors affected by potential market failure and externalities, such as utilities. Figure 4 shows SOEs' share of total employment in $21 \mathrm{EU}$ countries. Together, the EU's SOEs have an employment share below 10 percent, which is much lower than that of the SOEs in China in 2015.

\section{Figure 4: Employment in SOEs, \% of total employment}

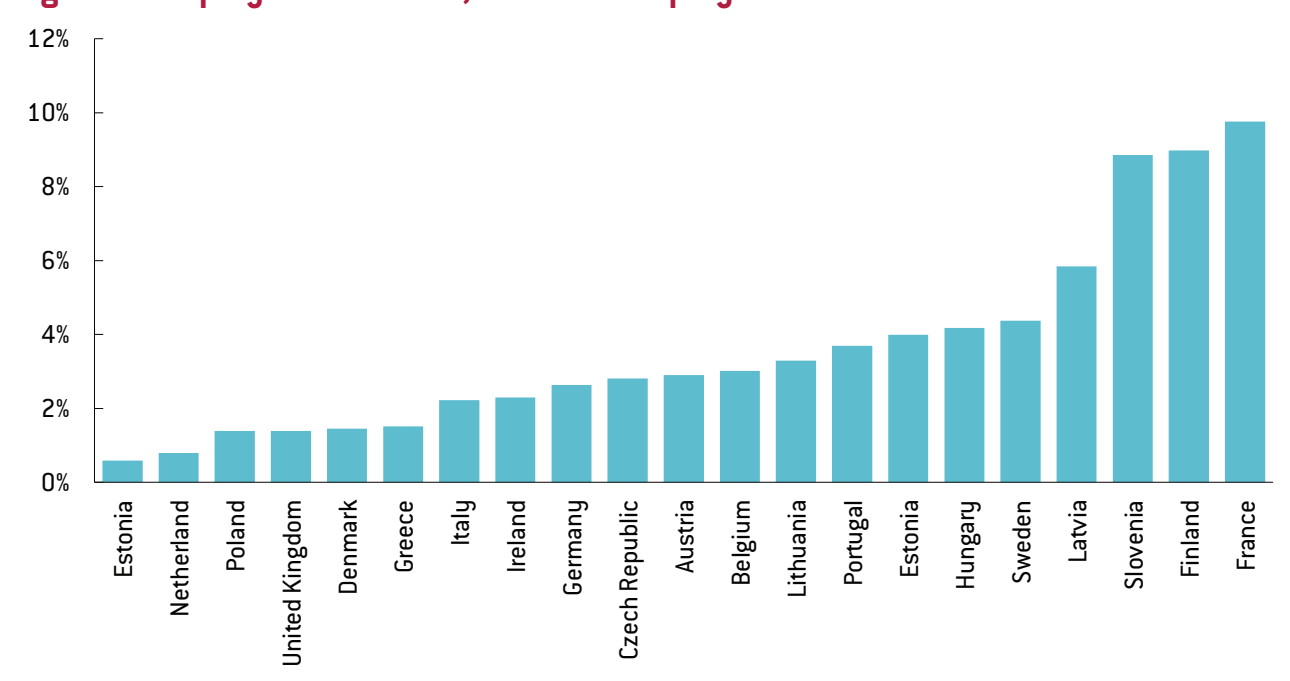

Source: Bruegel based on European Commission (2016), OECD, World Bank and Eurostat.

7 Colin Simpson, 'China's Reform of SOEs May Look a Little Odd to the West: Goldman', Bloomberg, 8 September 2016, available at https://www.bloomberg.com/news/articles/2016-09-08/goldman-sachs-sees-chinese-soe-reform-just-not-as-west-knows-it.

8 See Forbes Global 2000, https://www.forbes.com/global2000/. 
Though relatively large, Chinese SOEs tend to perform worse than their private peers. We calculated the assets and profit distribution of Chinese listed companies - SOEs and private firms. On average, SOEs own more assets than private firms but their profitability is lower (Figure 5). Our results are in line with those of Hsieh and Song (2015).

\section{Figure 5: State-owned enterprises [SOEs] versus private-owned enterprises [POEs] in asset and profit performance}
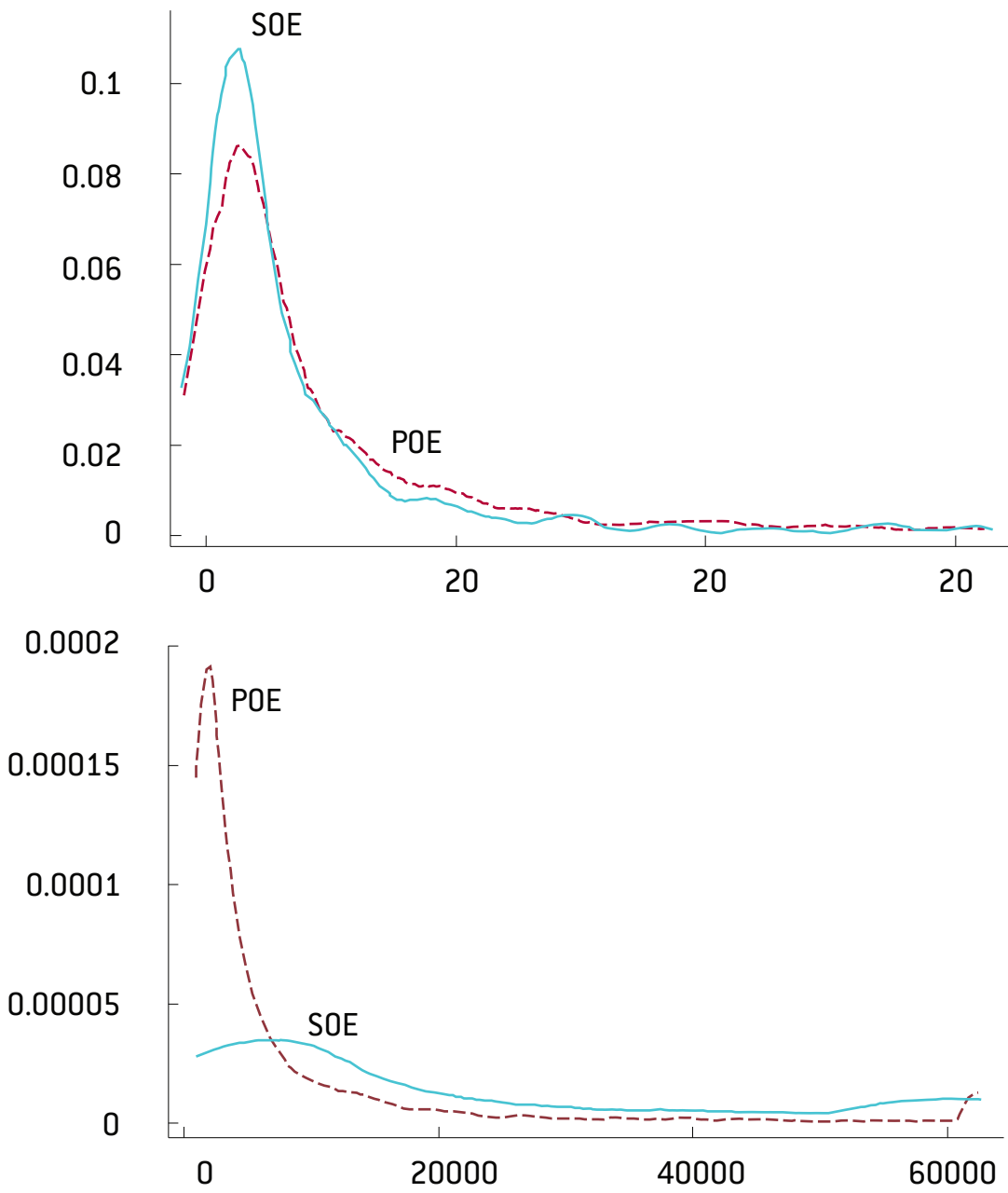

Source: Bruegel. Note: we calculated the probability distribution of the listed companies' assets (left) and profits (right) for Chinese SOEs andPOEs separately. To make sure our results are not sensitive to extreme values, data is truncated with firms above and below 5 percentiles for both variables.

Another important characteristic of Chinese SOEs is their industry coverage. Chinese SOEs seem to be much more engaged in manufacturing than European SOEs. More than 30 percent of Chinese SOEs are in the manufacturing sector and 55 percent of SOE employees work for manufacturing firms. The equivalent EU figures are 2.8 percent and 4.8 percent (Table 3). This is not so surprising if we consider that the manufacturing sector is larger in China, but this is not the whole story. The figures also highlight the Chinese government's industrial policy to develop what has long been a key strategic sector. 
Table 3: Sectoral distribution of SOEs in China and the EU: number of firms and employment

\begin{tabular}{ccccc}
\hline & \multicolumn{2}{c}{$\begin{array}{c}\text { Number of sectorial } \\
\text { SOEs/Total SOEs }\end{array}$} & \multicolumn{2}{c}{$\begin{array}{c}\text { Employment of } \\
\text { sectorial SOEs/ Total } \\
\text { SOEs }\end{array}$} \\
\cline { 2 - 5 } & China & EU & China & EU \\
\hline Agriculture, forest, fishing & $2.21 \%$ & $0.70 \%$ & $1.69 \%$ & $2.48 \%$ \\
\hline Manufacturing & $31.32 \%$ & $2.81 \%$ & $55.48 \%$ & $4.81 \%$ \\
\hline Services & $66.47 \%$ & $96.49 \%$ & $42.83 \%$ & $92.71 \%$ \\
\hline
\end{tabular}

Source: Bruegel based on Source: (1) Chinese National Bureau of Statistics; (2) Author's calculation based on BvD Amadeus/Orbis data set. Kalemli-Ozcan et al. (2015) presents a comprehensive introduction of the dataset.

To further highlight the extensive presence of SOEs in China, even among large firms, Table 4 shows the sectoral breakdown of the revenues of Chinese firms for state-owned, private-owned and foreign-owned firms. Chinese SOEs lead in many strategically important sectors beyond manufacturing, while foreign ownership is very limited even in sectors that are officially open to foreign competition.

Table 4: Sectorial sales distribution of SOEs, POEs and FOEs in China in 2008

\begin{tabular}{lccc}
\hline & SOE & POE & FOE \\
\hline Health & $58.92 \%$ & $41.06 \%$ & $0.02 \%$ \\
\hline Wholesale and Retail & $2.20 \%$ & $97.73 \%$ & $0.08 \%$ \\
\hline Culture & $24.43 \%$ & $75.26 \%$ & $0.30 \%$ \\
\hline Education & $54.71 \%$ & $44.36 \%$ & $0.94 \%$ \\
\hline Finance & $34.06 \%$ & $64.85 \%$ & $1.09 \%$ \\
\hline Accommodation & $21.74 \%$ & $76.78 \%$ & $1.48 \%$ \\
\hline Real Estate & $25.96 \%$ & $71.60 \%$ & $2.44 \%$ \\
\hline Environment & $7.32 \%$ & $90.11 \%$ & $2.57 \%$ \\
\hline Research & $43.65 \%$ & $53.51 \%$ & $2.83 \%$ \\
\hline Lease and Business & $33.94 \%$ & $62.28 \%$ & $3.78 \%$ \\
\hline Restaurant & $26.94 \%$ & $64.65 \%$ & $8.41 \%$ \\
\hline Manufacturing & $4.00 \%$ & $86.96 \%$ & $9.04 \%$ \\
\hline Sourcen & $15.11 \%$ & $75.26 \%$ & $9.63 \%$ \\
\hline
\end{tabular}

Source: Bruegel based on China's Economic Census Data. Note: FOE = foreign-owned enterprise

\section{The special environment for Chinese SOEs}

The fact that Chinese SOEs are generally larger and more pervasive than their global peers, but are also less profitable than private companies has its roots in the special corporate governance of SOEs. The appointment of SOEs' managers is still political, at least to some extent. Before 1992, SOEs' managers were government officials. After China's deepening market economy reform, the method of selecting SOE leaders was changed to a combination of official recommendation and market recruitment. Nevertheless, given that most SOE executives still retain an administrative rank, prospects for promotion in SOEs are significantly influenced by political decisions. A second reason for the relatively lower profitability of Chinese SOEs is their compliance with non-economic administrative orders. This is very hard to quantify but can be illustrated by a number of examples. A well-known issue is the treatment of overcapacity in SOEs. Bankruptcy is not an option for fear of its social impact through increased unemployment. Therefore, many steel companies have had no choice but to turn 
into unprofitable 'zombie enterprises'. Such non-economic orders can come from local, as well as central, government. A recent example is the Beijing government's political objective to reduce the population density in Beijing. To do this, the Beijing government requires some SOEs in Beijing's urban region to move to suburban areas, regardless of the potentially negative impacts on profits and employees ${ }^{9}$.

However, it is also because of SOEs' connections to the political hierarchy that they have access to benefits from the government, such as cheaper and easier access to financing than is available to private enterprises. Other sources of preferential treatment for SOEs seem to raise even greater levels of concern, according to an OECD survey (Table 5).

Table 5: Types of preferential treatment for SOE investments

\begin{tabular}{lccc}
\hline \multirow{2}{*}{ Type of preferential treatment } & \multicolumn{3}{c}{ Level of concern } \\
\cline { 2 - 4 } & Strong & Somewhat & Low \\
\hline Preferential financing & $15 \%$ & $62 \%$ & $23 \%$ \\
\hline Explicit/implicit guarantee & $15 \%$ & $31 \%$ & $54 \%$ \\
\hline Outright subsidies & $38 \%$ & $23 \%$ & $39 \%$ \\
\hline Regulatory exemptions & $25 \%$ & $33 \%$ & $42 \%$ \\
\hline Position in domestic marketplace & $38 \%$ & $39 \%$ & $23 \%$ \\
\hline Access to state information & $46 \%$ & $36 \%$ & $18 \%$ \\
\hline
\end{tabular}

Source: OECD (2016)

\section{Will global consumers benefit from Chinese SOEs? Not necessarily}

One could make a case that Chinese SOEs might not foster competition but could still be good for global consumers because they drive prices down even in tradable sectors, such as manufacturing. More specifically, given the intrinsic advantages SOEs have, coupled with their relatively lower profitability and managerial efficiency, the key question is whether such undue advantages can enable SOEs to set lower-than-equilibrium prices, which could possibly undercut competitors. Even if Chinese SOEs are capable of setting prices lower than their marginal costs because of subsidies (ie conduct dumping policies), and could thus weaken the EU's competitive environment, the final impact on welfare for the EU is ambiguous, because the consumer can benefit from lower prices and increased product variety. In that regard, market access seems to be the key factor for tilting the balance from a positive to a negative impact, according to Brander and Krugman (1983). In other words, market access helps maintain consumer welfare when dumping happens. The problem is that market access is indeed an issue in China, not only for foreign companies but even for private Chinese companies. This is why it is hard to argue that consumer welfare might be increased as a consequence of lower prices being set by Chinese SOEs.

\section{Should the focus be on SOEs when looking at market dominance and its consequences?}

Chinese private firms, including many in the manufacturing sector, were partially privatised in the late 1990s and early 2000s but still retain strong connections to the Chinese government. More specifically, five percent of Chinese private firms are under the direct control of Communist Party of China (CPC) members (Milhaupt and Zheng, 2015), and even non-party

9 McKinsey \& Company Blog, 'Why China Should Move State-Owned Enterprises Out of Beijing', 22 October 2015, available at http://mckinseychina.com/why-china-should-move-state-owned-enterprises-out-of-beijing/. 
entrepreneurs are also likely to pursue political resources and sometimes recruit CPC members or those people with relationships with government, in order to improve their chances of accessing scarce resources. A striking example is that more than 150 Chinese billionaires belong to a group of lawmakers in the National People's Congress, China's top legislature, or to the Chinese People's Political Consultative Conference, the leading political advisory board ${ }^{10}$. More generally, Milhaupt and Zheng (2015) show striking similarities between SOEs and some special private companies, leading them to argue that "drawing a stark distinction between SOEs and privately owned firms (POEs) misperceives the reality of China's institutional environment." In the same vein, a number of surveys conducted by Chinese officials ${ }^{11}$ show that private firms directly owned by Party members and those related to political elites obtained significantly more bank loans than others. This result is also verified by Kung and Ma (2014), who find that China's poor environment in terms of property rights has not affected private enterprises much because, in such an environment, many private business owners devote time and money to developing political connections with the government in exchange for looser regulation and easier access to finance, which is similar to the general environment for SOEs.

\section{The EU's concerns about Chinese SOEs: is it seeing the whole picture?}

The increasing economic magnitude of China's SOEs, and their eagerness to acquire foreign assets, has come as a shock for many European corporates. Some examples of recent European acquisitions by Chinese corporates are Pirelli by ChemChina and Louvre Hotels by Shanghai Jinjiang.

While Chinese corporates expand abroad, EU corporates seem to have increasing difficulty in accessing China's market. In this context, China has introduced a massive plan to support its own manufacturing industrial, the China Manufacturing 2025 Initiative. The ultimate goal of this initiative is to further enhance competitiveness in ten critical sectors, including new energy and rail transport equipment. Because targets have been set for the amount of local content, it seems clear that this plan will make it even more difficult for foreign investors to access China's market. According to a business confidence survey conducted in 2016, 57 percent of European firms believe that China's environmental regulations strongly disadvantage foreign companies (European Union Chamber of Commerce in China, 2016).

Chinese SOEs, aided by government industrial policy support schemes, have become major competitors for European firms. Figure 6 shows the number of companies included in the Forbes Global 2000 from China and ten major European countries. Excluding the UK, the number of Chinese Forbes Global 2000 firms has already reached the sum of the number of firms from all the other nine countries (France, Germany, Italy, Spain, Russia, Sweden, Netherlands, Ireland and Denmark). Competitive concerns are especially pressing for European manufacturers, because manufacturing is where China traditionally has a comparative advantage, and because of China's ambitious Manufacturing 2025 Initiative, which seeks to further strengthen the competitiveness of Chinese firms.

10 CNN, 'China's richest lawmakers are worth over $\$ 500$ billion', 3 March 2017, available at http://money.cnn. com/2017/03/03/news/economy/billionaire-chinese-lawmakers-npc/.

11 The survey was conducted through face-to-face interviews in 1995, 2000, 2006 and 2010 by a CPC central committee department, the United Front Work Department, and two ministry level central government agencies, The National Association of Industry and Commerce, and The State Administration for Industry and Commerce. To make the survey representative of the population of nationwide registered private firms, a stratified random sampling procedure was applied. See Guo et al (2014). 


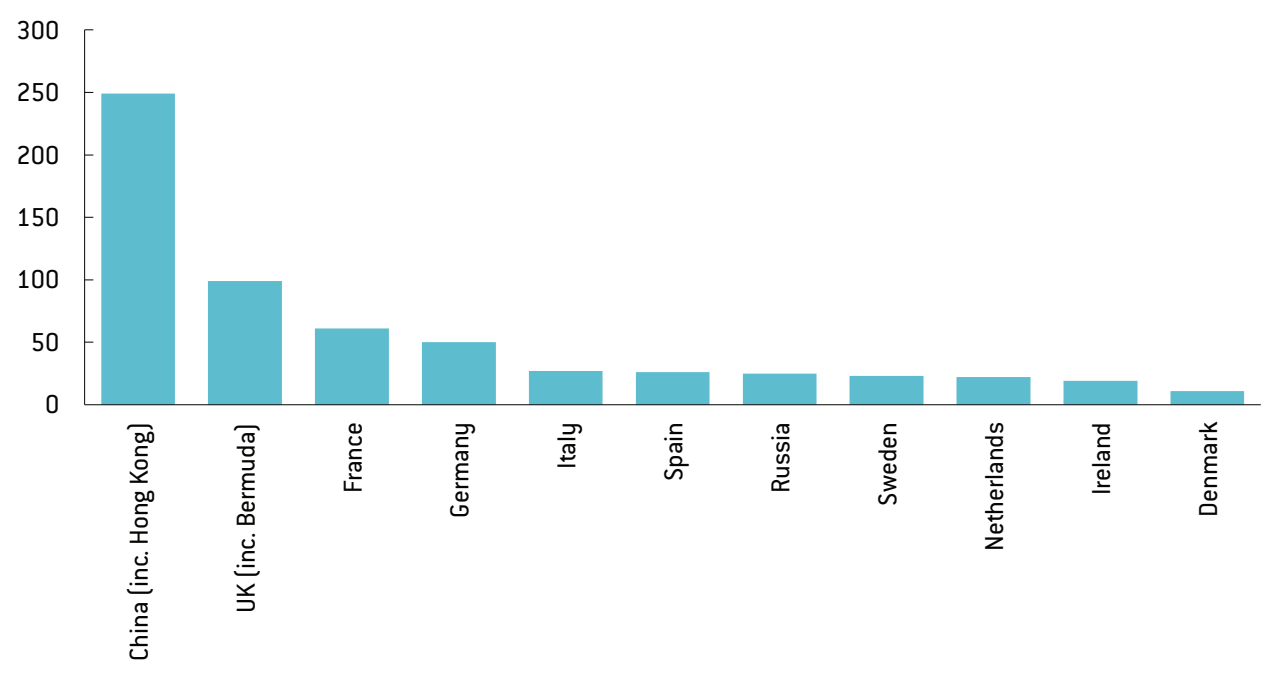

Source: Bruegel based on Forbes.

Against this backdrop, the EU is also taking steps to revive its industrial sector but within a very different framework, which aims to preserve competition and avoiding distortions (Veugelers, 2013). China's rising SOEs and the support they receive undoubtedly challenge the EU's spirit of competition and even its industrial policy. As such, correcting the apparently undue advantages that Chinese SOEs enjoy is an obvious policy target for the EU in the ongoing negotiations with China on a BIT.

From a practical point of view, however, targeting SOEs in the BIT negotiation might not be the best strategy for the EU to tackle this concern. As we have noted, a number of Chinese private companies also benefit from political access, similarly to the SOEs. If the EU were to set particularly rigorous rules for Chinese SOEs, it could leave more room for politically-connected Chinese private firms to gain government support for mergers and acquisitions in the European market. It is also hard to argue that all Chinese SOEs behave in the same way. Zhao (2015) finds evidence of a competitive environment for a number of Chinese SOEs insofar as they make investment decisions without government influence.

On this basis, the EU should not impose specific conditions on SOEs within the EU-China BIT, but should rather push for general policies that apply to both SOEs and private companies. In other words, instead of focusing on ownership, the EU should look into the state-centred institutional framework in which firms operate in China and how that might give them an advantage over European companies. The most important advantage Chinese companies enjoy is the difficult access to the Chinese market that their foreign competitors face. Therefore, liberalising market access is the most urgent step to be taken in order to create a level playing field so that European firms can compete with Chinese SOEs. This relates to the second aspect of the EU-China BIT: European investment in China.

\section{European companies investing in China}

European companies have long been present in China and have accumulated a stock of FDI of $€ 357$ billion if Hong Kong is included. Though the flow of FDI has stagnated since 2011, China remains an important market for many European corporations.

From the perspective of European companies investing in China, the first and foremost issue is market access. The EU Chamber of Commerce in Beijing has reported increasingly unfair treatment of foreign companies (European Union Chamber of Commerce in China, 2016a), and the OECD ranks China the second most restrictive country for FDI in the world, 
with only the Philippines more restrictive ${ }^{12}$. The question is whether this is related to the pervasive role of SOEs in the Chinese economy.

The answer, from our perspective, is that even Chinese private companies are denied access to some key sectors in the Chinese market on the grounds of security (including economic security) and based on a web of different laws and regulations, the most important being the anti-monopoly law. As we have shown (Table 4), the sectoral distribution of Chinese SOEs confirms that they are particularly favoured in the sectors considered strategically important by the government, including energy, infrastructure, utilities and finance. The EU Chamber of Commerce in China (2016b) finds these sectors to be the most difficult for European firms to access.

\section{Policy suggestions for the European Union}

Our analysis shows that Chinese SOEs differ from European SOEs in many ways and represent a risk of unfair competition for EU companies in both China and Europe. However, the EU should not over-focus on SOEs in the EU-China BIT negotiations because some large Chinese private companies also benefit from preferential market access in China, which also gives them a comparative advantage when operating abroad.

The first priority issue that an EU-China BIT should pursue is market liberalisation, so that any market access granted through the BIT puts European companies on an equal footing to their Chinese competitors (even with SOEs). This obviously requires, at least, reciprocity. In fact, market liberalisation is important not only for foreign companies but also for Chinese private companies so that gains are also shared with China (European Parliament, 2016).

Within the negotiation of the EU-China BIT, it seems important for the EU to continue to pursue reciprocity in terms of the treatment of corporate governance and, more generally, market access. Many concerns about the behaviour of SOEs are rooted in their complex corporate structures, which result in limited disclosure of their financial information. Beyond the EU's bilateral negotiations with China, one could think of other - multilateral - venues through which to pursue more market-driven corporate governance for Chinese SOEs. The most obvious route would be for China to become a member of OECD or, at least, to comply voluntarily with global principles of corporate governance. Such measures would be in the EU's interests and in the interests of China, which has repeatedly declared its determination to continue with its economic liberalisation. Pressure from the EU can only but help Chinese authorities push for further liberalisation.

In terms of specific aims for the EU-China BIT, the first priority, clearly based on the principle of reciprocity, should be that China's 'negative list' for market access should be narrowed considerably and extended beyond China's special economic zones to the whole Chinese territory. This goal remains distant as China's negative list continues to get longer, underpinned by a law that can limit investment for national security - or even economic - reasons ${ }^{13}$. FDI is highly restricted in China outside the special economic zones, with foreign investment permitted in very few sectors (positive list) and requirements to comply with as many as three foreign company laws ${ }^{14}$. A shorter negative list with broader coverage would significantly lift

12 OECD Database: FDI regulatory restrictiveness index, updated on 27 March 2017

13 China has stipulated rigorous censorship rules even for the special free trade zones. See http://www.gov.cn/ zhengce/content/2015-04/20/content_9629.htm.

14 'China advances foreign investment and negative list reform with seventh draft catalogue', see http://www.linklaters.com/Insights/AsiaNews/LinkstoChina/Pages/China-advances-foreign-investment-negative-list-reform-seventh-draft-catalogue.aspx. 
market access restrictions in the currently prohibited industries for EU companies. Opening up more sectors would be mutually beneficial, as it would help China further liberalise.

The second issue for the EU-China BIT relates to market access beyond the treatment of foreign companies. As we have noted, a key advantage for Chinese SOEs is their favourable access to certain industries. The Chinese government sometimes even uses anti-monopoly laws to protect the interests of some specific companies - and not only SOEs (Epstein, 2014). Revising the anti-monopoly law and other legal protections that benefit SOEs relative to other corporations are also essential and would be beneficial for China.

Third, the EU should build a firewall against potential problems related to Chinese investment in Europe. The two key instruments in this respect are the EU's competition policy and dispute resolution framework to regulate the operations of Chinese SOEs in the EU. Identifying unfair behaviour by a firm can be easier after a firm reveals its status by operating in the EU market. An appropriate dispute settlement mechanism can protect both European and Chinese corporates. Among the different options, an investor-state dispute settlement system (ISDS) seems to be favoured ${ }^{15}$ internationally, but would need to be revised so that governments (either China or EU governments) do not fall prey to corporates suing them without clear justification. Furthermore, in the Chinese case, the very close links between corporates and the Chinese government (especially when operating abroad) could make ISDS a double edged sword for the EU, because in certain cases China could, for its own purposes, support its enterprises in suing EU companies. In addition, the implementation of the ISDS might be difficult in China where experience with investor-state arbitration is rather limited and there is very low probability that the Chinese government will enforce foreign court decisions (US-China Economic and Security Review Commission, 2016). A revision of the ISDS is thus warranted to balance the interests of the parties in the BIT negotiation ${ }^{16}$.

\section{References}

Brander, James A. and Paul Krugman (1983) 'A Reciprocal Dumping Model of International Trade', NBER Working Paper No.1194, National Bureau of Economic Research

Epstein, Richard A. (2014) 'Curbing the Abuses of China's Anti-Monopoly Law: An Indictment and Reform Agenda', George Mason University School of Law, available at https://sls.gmu.edu/cpip/ wp-content/uploads/sites/31/2014/04/Curbing-the-Abuses-of-Chinas-Anti-Monopoly-Law.pdf

European Commission (2016) 'State-Owned Enterprises in the EU: Lessons Learnt and Ways Forward in a Post-Crisis Context', Institutional Paper 031, July

European Parliament Briefing (2016) 'State-owned Enterprise (SOE) Reforms in China: A Decisive Role for the Market at Last?' EPRS Briefing, available at http://www.europarl.europa.eu/RegData/etudes/ BRIE/2016/583796/EPRS_BRI(2016)583796_EN.pdf

European Union Chamber of Commerce in China (2016) European Business in China: Business Confidence Survey, available at http://www.europeanchamber.com.cn/en/publications-archive/516/ Business_Confidence_Survey_2017

European Union Chamber of Commerce in China (2016a) Annual Report 2016, available at http://www. europeanchamber.com.cn/en/publications-archive/514/Annual_Report_2016

European Union Chamber of Commerce in China (2016b) 'European Business in China Position Paper 2016/2017, available at http://www.europeanchamber.com.cn/en/publications-position-paper

Guo, Di, Kun Jianga, Byung-Yeon Kimb and Chenggang Xua (2014) 'Political economy of private firms in China', Journal of Comparative Economics 42 (2): 286-303

15 China is now more in favour of including ISDS in trade or investment deals, as shown by the FTA with Australia that was signed in 2014.

16 The EU has already put forward a different proposal, namely the International Court System, to correct the alleged shortcomings of ISDS, but not all EU countries agree because it would imply giving companies a status close to sovereignty status. 
Hanemann, Thilo and Mikko Huotari (2016) A New Record Year for Chinese Outbound Investment in Europe, MERICS and Rhodium Group, available at https://www.merics.org/en/media-contact/pressreleases/a-new-record-year-for-chinese-outbound-investment-in-europe/

Hongtu, Zhao (2015) ‘The Myth of China's Overseas Energy Investment', East Asia Forum Quarterly, 4 March

Hsieh, Chang-Tai and Zheng Song (2015) 'Grasp the Large, Let Go of the Small: The Transformation of the State Sector in China', Brookings Papers on Economic Activity, available at https://www.brookings. edu/wp-content/uploads/2016/07/2015a_hsieh.pdf

Kalemli-Ozcan, Sebnem, Bent Sorensen, Carolina Villegas-Sanchez, Vadym Volosovych and Sevcan Yesiltas (2015) 'How to Construct Nationally Representative Firm Level Data from the ORBIS Global Database', NBER Working Paper No. 21558, National Bureau of Economic Research

Kung, James Kai-Sing and Chicheng Ma (2016) 'Friends with Benefits: How Political Connections Help Sustain Private Enterprise Growth in China, Economica, October

Mihaupt, Curtis J. and Wentong Zheng (2015) 'Beyond ownership: state capitalism and the Chinese firm', Georgetown Law Journal 103 (3): 665-722

OECD (2016) State-Owned Enterprises as Global Competitors A Challenge or an Opportunity, OECD Publishing, Paris

US-China Economic and Security Review Commission (2016) 'Policy Considerations for Negotiating a US-China Bilateral Investment Treaty', Staff Research Report, August

Veugelers, Reinhilde (ed) (2013) Manufacturing Europe's Future, Blueprint 21, Bruegel 